\title{
Afforestation with Pinus nigra Arn ssp salzmannii along an elevation gradient: controlling factors and implications for climate change adaptation
}

\author{
Manuel Esteban Lucas-Borja ${ }^{1}$ (D) Xin Jing ${ }^{2} \cdot$ David Candel-Perez $^{3} \cdot$ Misagh Parhizkar $^{4} \cdot$ Francisco Rocha $^{5}$. \\ Mehdi Heydari ${ }^{6} \cdot$ Miriam Muñoz-Rojas ${ }^{7,8} \cdot$ Demetrio Antonio Zema $^{9}$
}

Received: 25 March 2021 / Accepted: 14 July 2021 / Published online: 22 July 2021

(c) The Author(s) 2021

\begin{abstract}
Key Message The first bottleneck in Spanish black pine survival through afforestation is the lack of resistance to drought in their initial life stages.

Abstract Spanish black pine (Pinus nigra Arn ssp. salzmannii) is the most widely distributed pine species in mountain areas of the Mediterranean Basin and is commonly used for afforestation in endangered and degraded areas. Despite its importance, little is known regarding the factors driving seedling survival for this species, which may hamper afforestation success in Mediterranean areas. In this study, we assessed the effects of seed origin and plantation site along a natural gradient with contrasting elevation and climatic conditions in a Mediterranean forest in Central-Eastern Spain. Our results showed: (1) higher seedling survival rates when seed origin differed from plantation site $(25.3 \pm 5.4 \%)$ compared to same origin and plantation site $(5.3 \pm 2.7 \%)$; (2) higher survival probability ( 20\%) for high and medium elevation seeds (colder and wetter locations) compared to the warmer and drier low elevation sites (15\%); (3) higher seedling survival ( 40\%) at higher elevation sites compared to low-elevation sites $(<20 \%)$; and (4) increased hazard of seedling death with decreasing elevation of the plantation site. We also reported a complete mortality at the drier sites after the first summer following the plantation. Overall, the combination of seeds from medium elevation and high elevation plantation sites increased the survival of Spanish black pine. These results have direct implications for forest management of Spanish black pine in Mediterranean regions, particularly in current and future climate change scenarios.
\end{abstract}

Keywords Afforestation $\cdot$ Seedling survival $\cdot$ Spanish black pine $\cdot$ Transplantation $\cdot$ Climate change $\cdot$ Species adaptation

Communicated by van der Maaten.

Manuel Esteban Lucas-Borja

ManuelEsteban.Lucas@uclm.es

1 Technical School of Agricultural and Mountain Engineering (ETSIAM), University of Castilla-La Mancha (UCLM), 02071 Albacete, Spain

2 Department of Earth and Environmental Sciences, KU Leuven, Celestijnenlaan 200E, 3001 Leuven, Belgium

3 Universidad Publica de Navarra, Campus de Arrosadía, 31006 Pamplona, Navarra, Spain

4 Soil Science Department, Faculty of Agricultural Sciences, University of Guilan, Rasht, Iran
5 Instituto Superior Técnico, University of Lisbon, 1049-001 Lisbon, Portugal

6 Department of Forest Science, Faculty of Agriculture, Ilam University, Ilam, Iran

7 Centre for Ecosystem Science, School of Biological, Earth and Environmental Sciences, The UNSW 11, Sydney, NSW 2052, Australia

8 School of Biological Sciences, The University of Western Australia, Crawley, WA 6009, Australia

9 Department AGRARIA, Mediterranean University of Reggio Calabria, Località Feo di Vito, 89122 Reggio Calabria, Italy 


\section{Introduction}

Preventing and reverting ecosystem degradation have become urgent and crucial goals for achieving land and ecosystem sustainability globally (Willemen et al. 2020). To accomplish these targets, the United Nations have declared 2021-2030 as the Decade on Ecosystem Restoration, calling for urgent and strong commitments to achieve transformational ecosystem restoration (Ockendon et al. 2018). Afforestation with native tree species can restore degraded forests and assist natural regeneration, particularly in fragile forestland ecosystems (Löf et al. 2019; Parhizkar et al. 2020). Afforestation practices can ensure the supply of seedlings to a particular forest area and have beneficial impacts on the environment, such as the improvement of microclimatic conditions in degraded sites, increased biodiversity (Wenhua 2004; El-Keblawy and Ksiksi 2005; Fiandino et al. 2018), carbon sequestration (Niu and Duiker 2006; Hernández et al. 2016) and an overall positive economic impact on degraded lands (Djorović et al. 2003; Zeng et al. 2018).

Spanish black pine (Pinus nigra Arn ssp. Salzmannii) is the most widely distributed pine species in mountain areas of the Mediterranean Basin (Barbéro et al. 1998) (Barbéro et al. 1998), and commonly used for afforestation in eroded areas after widespread abandonment of arable land (Campo et al. 2019). These pine forests are classified as "habitats of European interest" and require specific conservation measures according to the Convention for the Conservation of European Wildlife and Natural Habitats (Resolution 4/1996), due to the lack of successful natural regeneration. Despite large efforts, several conservation and management challenges have been identified for Spanish black pines. These challenges include irregular masting events (the synchronous production of large seed crops within a population every six years), the dependence of seed mass on climatic conditions, seed predation, summer drought periods over three consecutive years, excessive grazing, and uncontrolled ploughing (Del Cerro et al. 2009; Lucas-Borja et al. 2011, 2012a, b; Tíscar-Oliver and Lucas-Borja 2010; Tíscar-Oliver et al. 2014). Failure in the natural regeneration of Spanish black pine has also been associated with unsuitable seed provenance and/or environmental conditions of plantation sites (Bischoff et al. 2010; Tíscar-Oliver and Linares 2014). Throughout historical times, this species has disappeared in some habitats due to crown wildfires (Morales-Molino et al. 2017) or by interspecific competition, mainly with Pinus pinaster Ait. (Barbéro et al. 1998).

Although seedling emergence and early growth of most species are largely controlled by climatic conditions at a broad scale, other factors are relevant at local scales, e.g., soil and site characteristics (Pigliucci 2001). In Mediterranean ecosystems, drought and soil desiccation are serious restrictions to seedling establishment, particularly after germination, due to long and dry summer periods (Moles and Westoby 2004). For the Spanish black pine, water availability is one of the most important factors affecting the success of initial recruitment (Tíscar-Oliver et al. 2011). Increases in severity, length and frequency of summer droughts can critically affect the dynamic processes, plant distribution, establishment, and growth of this pine species (Lucas-Borja et al. 2017). Thus, projected decreases in precipitation and increases in temperature in future climate scenarios may aggravate their vulnerability and alter their current distribution in the Mediterranean Basin (Lindner et al. 2010; López-Serrano et al. 2009). Also, natural enemies like pathogens and seed predators can be important drivers limiting the success of early-stage recruitment (Dulamsuren et al. 2013; Ordóñez and Retana, 2004).

Several forest management strategies such as in-situ use of extant species, or ex-situ assisted-migration, i.e., humanassisted shift of plants to more suitable habitats, may be effective for improving plant survival (Löf et al. 2019). Assisted population migrations and translocation to different latitudes or elevations have also been proposed as a climate mitigation measure. However, tree adaptation to changing environments has shown contradictory results i.e., under global warming scenarios of forest upslope migration, high-elevation variants may be outperformed by lowelevation ones and vice-versa (Gray et al. 2016; Mathiasen and Premoli 2016; Wang et al. 2019). The use of autochthonous seeds, more adapted to dry and warm climatic conditions at lower elevations, has been suggested as an effective approach to improve afforestation success under changing conditions and to support the process of species diversification (Garrido et al. 2012). The lower adaptation capacity of the species above the treeline (high-elevation) may be considered as a negative trait, as species from lower altitudes are more plastic in their responses to drought and temperature during germination (Walder and Erschbamer 2015). Some studies have remarked that climate warming may have already disrupted local adaptation. Nevertheless, this is a unclear equation as higher temperatures can either promote (seed germination) or threaten (seedling establishment) different early life-history stages of plants (VázquezRamírez and Venn 2021). Despite the importance of elevation for species adaptation to a changing climate, important influencing factors such as seed origin and plantation site remain largely unexplored.

Here, we aimed to assess whether the interaction between seed origin and plantation site had an effect on the survival of Spanish black pine seedlings one year after afforestation 
along an altitudinal gradient (low, medium and high elevation) in Central-Eastern Spain. In this Mediterranean-climate area, black pine is naturally distributed along with an altitudinal range. We hypothesized that throughout the first year after afforestation: (1) seeds from warmer and drier locations would be more adapted to drought conditions compared to seeds from other origins; and (2) plantation sites at higher elevation locations (with lower air temperature and higher precipitation) could promote survival of seedlings.

\section{Materials and methods}

\section{Study area}

This study was carried out between 2011 and 2012 in the Cuenca Mountains (Central-eastern Spain). Climate in this area is characterized by wet and cold winters, and dry and hot summers. During the monitoring period at the studied sites, precipitation and temperature ranges were 204-371 mm and 2.6-4.7 ${ }^{\circ} \mathrm{C}$, respectively, in winter, and 86-117 mm and $18.8-21.7{ }^{\circ} \mathrm{C}$ in summer. Precipitation was below the long-term (30 year) average (except for November 2012), showing the drought condition of the study area during the monitoring period. The temperature anomaly was less pronounced, and the mean temperatures in 2011-2012 were similar to the long-term average (Lucas-Borja et al. 2020). In Spain, Spanish black pine is distributed between 900 and 2200 m.a.s.l. (Zaghi, 2008). Within the study area (Cuenca Mountains), Spanish black pine is naturally distributed between 1000 and 1700 m.a.s.l. and dominates the forest composition as nearly pure stands. Mixed stands of Spanish black pine and Pinus Pinaster grow at the lowest elevations (about $1000-1100 \mathrm{~m}$ ) of this altitudinal range, while Spanish black pine is mixed with Pinus Sylvestris at higher elevations (about 1400-1700 m). At the lower and upper extremes of the altitudinal gradient, Spanish black pine appears displaced as isolated populations that are further fragmented into smaller stands (Lucas-Borja et al. 2010). Slope was between $2-7 \%$ and aspect was north across all plots in our study.

Black pine forests in the Cuenca Mountains have traditionally been managed using the shelterwood system, with a shelter-period of 20-25 years and a rotation period of 100-125 years (Tíscar-Oliver et al. 2011). This method consists of a uniform opening of the canopy for regeneration purposes without site preparation (Lucas-Borja et al. 2011). Ground vegetation is composed of herbaceous vegetation (Eryngium campestre L., Geranium selvaticum L., Festuca rubra L. and Cirsium acaule L.) and small shrubby species (mainly Thymus bracteatus L.). Main soil types are calcium-rich and overlie shallow calcareous bedrocks (United States Department of Agriculture, 1999). Lithic haploxeroll to Typical xerorthent are the dominant soils in the study area (Lucas-Borja et al. 2011).

\section{Experimental sites}

Three experimental sites along an elevation gradient were selected in the studied area: (1) Las Majadas (hereinafter indicated as "high elevation"; 1416 m.a.s.l.); (2) Los Palancares y Agregados ("medium elevation"; 1210 m.a.s.l.); and (3) El Cardozo y Los Llecos ("low elevation"; 1082 m.a.s.l.). Each of the three sites covered around five ha of naturally regenerated mature pine stands (mean age of 85-110 years, and mean density of 700-800 trees per ha). Climate characteristics for each site are described in Table 1.

Table 1 Climatic data of the three experimental sites (Cuenca Mountain Range, Central-Eastern Spain) (Source: Meteorology Spanish Agency, AEMET)

\begin{tabular}{|c|c|c|c|c|c|c|c|}
\hline \multirow[t]{2}{*}{ Site } & \multirow[t]{2}{*}{ Coordinates } & \multirow{2}{*}{$\begin{array}{l}\text { Elevation (m } \\
\text { a.s.l.) }\end{array}$} & \multicolumn{2}{|c|}{ Mean rainfall $(\mathrm{mm})$} & \multicolumn{3}{|l|}{ Mean temperature $\left({ }^{\circ} \mathrm{C}\right)$} \\
\hline & & & Annual & Summer & Annual & $\begin{array}{l}\text { Min. of cold- } \\
\text { est month }\end{array}$ & $\begin{array}{l}\text { Max. of hottes } \\
\text { month }\end{array}$ \\
\hline $\begin{array}{l}\text { Las Maja- } \\
\text { das (High } \\
\text { Elevation) }\end{array}$ & $\begin{array}{l}40^{\circ} 15^{\prime} \mathrm{N} \\
1^{\circ} 56^{\prime} \mathrm{W}\end{array}$ & 1416 & 950 & 115 & 9.6 & -4.5 & 28.3 \\
\hline $\begin{array}{l}\text { Los Palan- } \\
\text { cares y } \\
\text { Agregados } \\
\text { (Medium } \\
\text { Elevation) }\end{array}$ & $\begin{array}{l}40^{\circ} 01^{\prime} \mathrm{N} \\
1^{\circ} 59^{\prime} \mathrm{W}\end{array}$ & 1210 & 595 & 99 & 11.9 & -0.5 & 30.5 \\
\hline $\begin{array}{l}\text { El Cardozo y } \\
\text { Los Llecos } \\
\text { (Low Eleva- } \\
\text { tion) }\end{array}$ & $\begin{array}{l}39^{\circ} 54^{\prime} \mathrm{N} \\
2^{\circ} 04^{\prime} \mathrm{W}\end{array}$ & 1082 & 612 & 57 & 12.2 & 3.2 & 31.2 \\
\hline
\end{tabular}




\section{Experimental design}

In January 2011, three plots of $30 \times 30 \mathrm{~m}$ (separated at least $300 \mathrm{~m}$ from each other) were randomly selected at each experimental site, i.e., high, medium, and low elevation. Site characteristics, e.g., slope, aspect, shrub composition and cover (zero canopy cover), herbal vegetation (Eryngium campestre L., Thymus bracteatus L., Geranium selvaticum L., Festuca rubra L. and Cirsium acaule L.), and soil type (typical Xerorthent and Leptosol) were similar among plots (Lucas-Borja et al. 2017). All plots were enclosed using a $1.5 \mathrm{~m}$ height fence of wire mesh $(1 \times 1 \mathrm{~cm})$ for protection against predators. In February 2011, at least 20-30 mature cones of Spanish black pine were collected from 10 trees randomly selected at each site. Cones were dried at $30{ }^{\circ} \mathrm{C}$ in the oven for $48 \mathrm{~h}$ to promote opening and collect the seeds. Seeds were then pooled by site and a germination test was performed on a sub-sample under controlled conditions in the laboratory to assess seed viability. Germination rates were over $95 \%$ for all sites without any difference (LucasBorja et al. 2017). Seeds were then kept refrigerated at $4{ }^{\circ} \mathrm{C}$ until the sowing experiment began.

A sample of 144 seeds (48 seeds per site) was randomly selected for the field experiment. Seeds were individually weighed and taken to an outdoor nursery in Albacete (704 m.a.s.1., $38^{\circ} 57^{\prime \prime} \mathrm{N}-1^{\circ} 52^{\prime} \mathrm{W}$,), 150,175 and $270 \mathrm{~km}$ far from the low, medium and high elevation sites, respectively. At the nursery, in late February-2011, seeds sampled from each site were sown $(1 \mathrm{~cm}$ depth) in individual containers $\left(1000 \mathrm{~cm}^{3}\right.$ of volume) in trays, each one filled with soil collected from the corresponding site. Trials were carried out using a randomized disposition of the trays with a periodical change of positions every 10 days, to avoid dissimilar growth conditions among replicates and treatments. In relation to seedling cultivation in the nursery, we did not fertilize any seedling. Each seedling was watered with the same water quality and quantity and all seedlings were under the same shading conditions.

At the end of March 2012, seedlings grown in the nursery were planted in the field experimental areas at the Cuenca Mountains Range. In relation to site preparation, seedlings plantation was made using manual holes $(0.75 \times 0.75 \times 0.75 \mathrm{~m})$. A total of 118 seedlings were used for the field experiment, after removing those dead or damaged during transportation from the nursery to the field site (Table 1). All seedlings and seeds used in this study were similar in height $(7.8 \pm 1.1 \mathrm{~cm}$ per seedling $)$ immediately after plantation) and weight $(9.7 \pm 10-3 \mathrm{~g}$ per seed immediately after plantation). Litter accumulation and competition from ground vegetation effects were avoided since litter and plants were previously removed from the sowing points.

The experimental design consisted of the following factors: (1) Transplantation ("home", seed origin matched the plantation site, vs. "away", seed origin differed the plantation site); (2) Seed origin (high, medium, and low elevation); and (3) Plantation site (high, medium, and low elevation). Moreover, the interactions (nine combinations) of seed origin and plantation site were also evaluated. Hereinafter the "transplantation", "seed origin" and "plantation site" factors are indicated with "T", "SO" and "PS", respectively. Seedlings $(n=118)$ were manually planted using a hoe and survival was monitored monthly from March 2012 to the end of the year. The number of seedlings planted at each plot can be seen in Table 2. Dates and causes of seedling death (mainly desiccation) were recorded.

\section{Statistical analyses}

Seedling survival was analysed using three methods (as in Cripps et al. 2018): (1) non-parametric Kaplan-Meier to estimate survival probability of seedlings (Therneau, and Grambsch, 2000); (2) non-parametric log-rank test to compare the seedling survival among the experimental factors;

Table 2 Summary of the number of seedlings (planted and alive) and seedling survival rate $(n=118)$ of Spanish black pine in Cuenca Mountains (Spain)

\begin{tabular}{|c|c|c|c|c|c|}
\hline \multirow{2}{*}{\multicolumn{2}{|c|}{ Factor }} & \multicolumn{2}{|c|}{$\begin{array}{l}\text { Number of seed- } \\
\text { lings }\end{array}$} & \multicolumn{2}{|c|}{$\begin{array}{l}\text { Seedling } \\
\text { survival (\%) }\end{array}$} \\
\hline & & Planted $^{1}$ & Alive $^{2}$ & Mean & SE \\
\hline \multicolumn{6}{|c|}{ Transplantation } \\
\hline \multicolumn{2}{|l|}{ Home } & 38 & 2 & 5.3 & 2.7 \\
\hline \multicolumn{2}{|l|}{ Away } & 80 & 20 & 25.3 & 5.4 \\
\hline \multicolumn{6}{|c|}{ Seed origin (elevation) } \\
\hline \multicolumn{2}{|l|}{ High } & 37 & 8 & 21.6 & 2.5 \\
\hline \multicolumn{2}{|l|}{ Medium } & 39 & 8 & 21.0 & 7.1 \\
\hline \multicolumn{2}{|l|}{ Low } & 42 & 6 & 14.9 & 7.9 \\
\hline \multicolumn{6}{|c|}{ Plantation site (elevation) } \\
\hline \multicolumn{2}{|l|}{ High } & 43 & 15 & 38.2 & 20.0 \\
\hline \multicolumn{2}{|l|}{ Medium } & 39 & 7 & 18.6 & 7.7 \\
\hline \multicolumn{2}{|l|}{ Low } & 36 & 0 & 0.0 & 0.0 \\
\hline \multicolumn{6}{|c|}{ Interaction seed origin $\times$ plantation site (elevation) } \\
\hline \multicolumn{6}{|c|}{ Seed origin Plantation site } \\
\hline High & High & 13 & 2 & 16.7 & 8.3 \\
\hline High & Medium & 12 & 6 & 50.0 & 14.4 \\
\hline High & Low & 12 & 0 & 0.0 & 0.0 \\
\hline Medium & High & 14 & 8 & 63.9 & 24.7 \\
\hline Medium & Medium & 13 & 0 & 0.0 & 0.0 \\
\hline Medium & Low & 12 & 0 & 0.0 & 0.0 \\
\hline Low & High & 16 & 5 & 38.1 & 31.2 \\
\hline Low & Medium & 14 & 1 & 8.3 & 8.3 \\
\hline Low & Low & 12 & 0 & 0.0 & 0.0 \\
\hline
\end{tabular}

SE standard error

${ }^{1}$ March 2012; ${ }^{2}$ December 2012 
and (3) Cox proportional hazard regression (hereinafter simply "Cox model") to determine the effects of seed origin, plantation site and their interaction on seedling survival. In the Kaplan-Meier method (Kaplan, 1958), the survival functions from lifetime data were estimated. More specifically, considering the day of seedling planting as the entry time (day zero), the "time to event" was measured, i.e., time elapsed from day zero until a particular event, for example, onset of seedling death. Based on time to event data, the seedling survival probability at time $t_{i}, S\left(t_{i}\right)$ was estimated as follows:

$S\left(t_{i}\right)=S\left(t_{i-1}\right)\left(1-\frac{d_{i}}{n_{i}}\right)$

where: $S\left(t_{i-1}\right)$ is the probability of seedlings being alive at $t_{i-1}$. $n_{i}$ is the number of seedlings alive before $t_{i}$. $d_{i}$ is the number of seedling death at $t_{i}$.

The estimated survival probability is a step function that $t_{0}=$ day zero and $S\left(t_{0}\right)=1$ and the values change only at the day of seedling death. Seedling survival probability for each experimental treatment was visualized using "survival curves". To compare survival probability among groups (i.e., the groups discriminated by the experimental factor, as mentioned above), a log-rank test was used (Harrington and Fleming, 1982) followed by Chi-square test. The logrank test was used to test the null hypothesis that there is no significant difference in survival probability among groups. The main advantage of this test is that no prior assumptions are needed about the survival distributions.

Since the Kaplan-Meier curves and log-rank tests are applied only to univariate analysis, the Cox model (Cox, 1972) was used to determine the effects of each factor considered for the Kaplan-Meier method and log-rank test on seedling survival, i.e., to examine whether the rate of seedling death is influenced by the factor. Therefore, the Cox model can be written as follows:

$$
\begin{aligned}
h(t)= & h_{0}(t) \cdot \exp \left(\beta_{i} x_{i}\right)=h_{0}(t) \cdot \exp \left(\beta_{T} \cdot T+\beta_{\mathrm{SO}} \cdot \mathrm{SO}\right. \\
& \left.+\beta_{\mathrm{PS}} \cdot \mathrm{PS}+\beta_{\mathrm{SO} \times \mathrm{PS}} \cdot \mathrm{SO} \times \mathrm{PS}\right)
\end{aligned}
$$

where: $h(t)$ is a "hazard" function, measuring the hazard of seedling death, $t$ is the survival time, $x_{i}$ is a covariate (in this study, the values of the experimental factors, $T, \mathrm{SO}, \mathrm{PS}$ and the interaction $\mathrm{SO} \times \mathrm{PS}), \beta_{i}$ are experimental coefficients, which measure the effect size of the factor (in this study, $\beta_{T}, \beta_{\mathrm{SO}}, \beta_{\mathrm{PS}}$ and $\left.\beta_{\mathrm{SO} \times \mathrm{PS}}\right), h_{0}(t)$ is the baseline hazard, which corresponds to the value of the hazard if all the $x_{i}$ are equal to zero.

The quantities exp $\left(\beta_{i}\right)$ are called hazard ratios (HR). A value of $\beta_{i}$ greater than zero, or, equivalently, a HR greater than one, indicates that as the value of the ith factor increases, the hazard of seedling death increases and thus the length of survival decreases; conversely, a negative $\beta_{i}$ (HR value lower than one) denotes a positive effect of that factor on seedling survival. To summarize, if $\mathrm{HR}=1$, the factor has not any effect on seedling survival, if $H R<1$, the death hazard is reduced, while, if $\mathrm{HR}>1$, the hazard is increased.

\section{Results}

The "home" seedlings (i.e., seedlings with the same seed origin than the plantation site) showed a lower survival probability $\left(\chi_{\mathrm{sq}}=9, \mathrm{df}=1, p=0.0027\right.$, Fig. 1$)$ and seedling survival $(5.3 \pm 2.7 \%)$ compared to the "away" seedlings, i.e., planted away from the place of the seed origin $(25.3 \pm 5.4 \%)$ (Table 2).

Survival rates at the end of the experiment were similar for seeds from high and medium elevations $(21.6 \pm 2.5 \%$
Fig. 1 Kaplan-Meier curve showing the survival probability of 'home' and 'away' for Spanish black pine's seedlings $(n=118)$ in Cuenca Mountains (Spain)

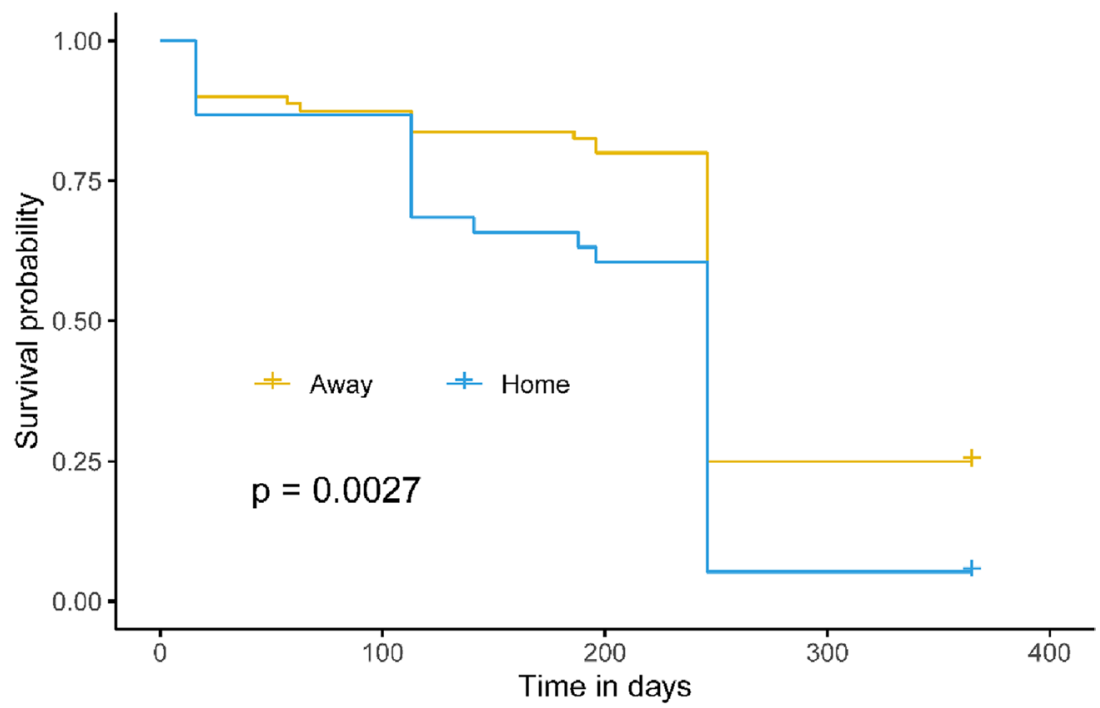


vs. $21.0 \pm 7.1 \%$, respectively), and higher than those recorded at low elevations $(14.9 \pm 7.9 \%)$ (Table 2$)$. Nevertheless, differences in survival probability for seedlings among groups were not significant (log-rank test, $p=0.14$, Fig. 2B). Across plantation sites, survival probability for seedlings was significantly different $\left(\chi_{\mathrm{sq}}=6\right.$, $\mathrm{df}=2, p=0.049$ ) (Fig. 2A). All the seeds planted in low elevation sites died, while seedlings in high elevation plantation sites showed the highest survival percentage $(38.2 \pm 20.0 \%)$ (Table 2).

The interactions between seed origin and plantation site had significant effects on the survival probability for seedlings (log-rank test with $\chi_{\mathrm{sq}}=45.6, \mathrm{df}=8, p<0.001$, Fig. 3) and large survival variability was observed among these combinations (Table 2). In more detail, none of the seedlings survived at the low plantation sites and at medium elevation
Fig. 2 Kaplan-Meier curve showing the survival probability for Spanish black pine's seedlings in Cuenca Mountains (Spain) considering transplantation (A) and seed origin (B) factors. $P$ value of the Log-Rank test is shown

Fig. 3 Kaplan-Meier curve showing the survival probability for Spanish black pine's seedlings in Cuenca Mountains (Spain) considering the interaction between seed origin and plantation site. The $P$ value of the Log-Rank test is shown
A Seed origin + High elevation + Medium elevation + Low elevation

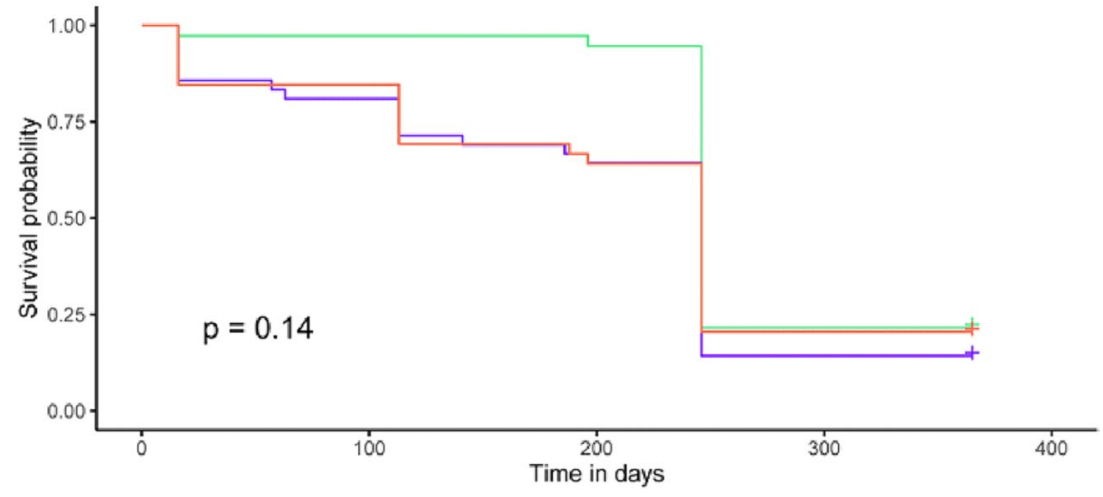

B Plantation site + High elevation + Medium elevation + Low elevation

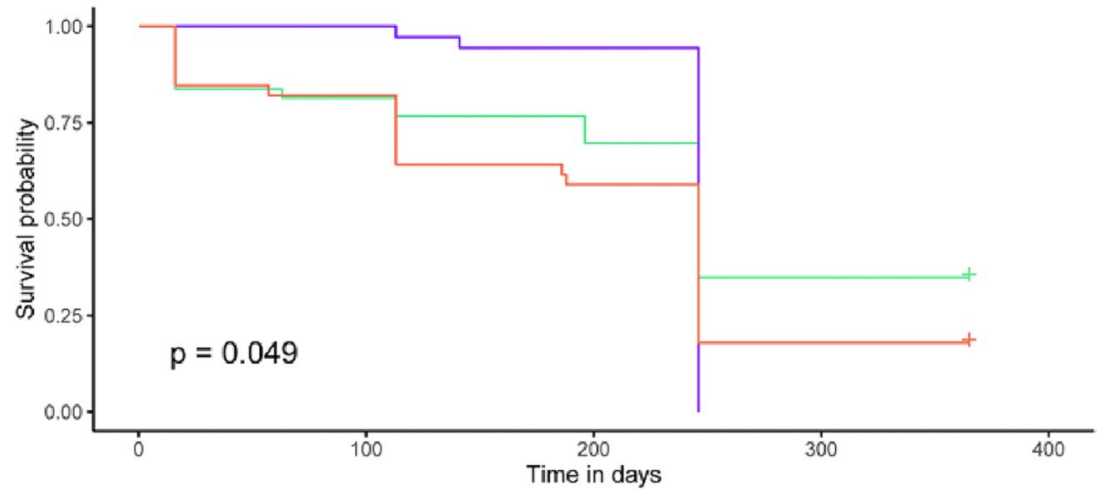

Seed origin=Low

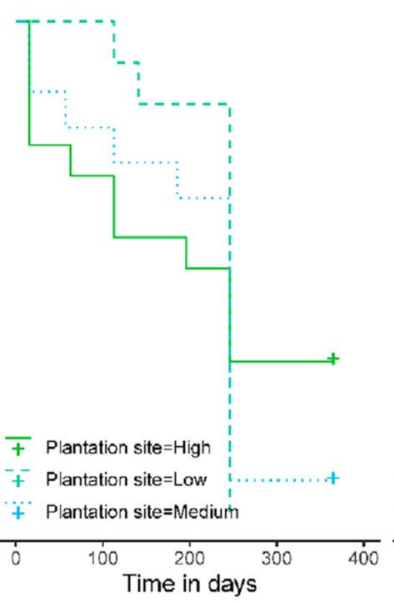

Seed origin=Medium

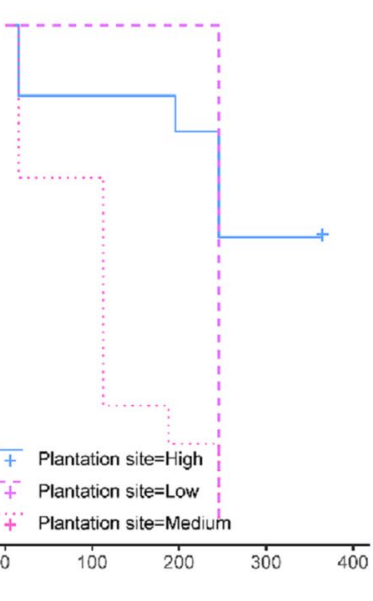


site with medium elevation seeds. Medium elevation seeds in high elevation plantation sites showed the highest survival percentage $(63.9 \pm 24.7 \%)$, followed by high elevation seeds in medium elevation plantation sites $(50.0 \pm 14.4 \%$, Table 2$)$.

The Cox model identified "transplantation" $\left(\chi_{\mathrm{sq}}=8.17\right.$, $\mathrm{df}=1, p=0.004)$, "plantation site" $\left(\chi_{\mathrm{sq}}=7.82, \mathrm{df}=2\right.$, $p=0.02)$ and the interaction between "seed origin" and "plantation site" ( $\left.\chi_{\mathrm{sq}}=17.73, \mathrm{df}=3, p<0.001\right)$ as the factors that most influenced the death hazard of seedlings (Fig. 4). Specifically, "home" seedlings had a significantly higher death hazard (mean HR $=5.8$ [2.8-11.8], $p<0.001$ ) compared to "away" seedlings $(\mathrm{HR}=1)$. The death hazard of seeds from low $(\mathrm{HR}=5.3$ [2.1-13.2], $p<0.001)$ and medium $(\mathrm{HR}=2.0[1.0-4.1], p=0.045)$ elevations was higher compared to the reference seeds (from high elevation, $\mathrm{HR}=1$ ). The HRs of plantation sites showed similar trends than the seed origins, since seedlings in plantation sites with low $(\mathrm{HR}=7.3$ [2.9-18.3], $p<0.001)$ and medium $(\mathrm{HR}=2.2$ [1.1-4.5], $p=0.024)$ elevations had higher death hazard compared to seedlings with plantation sites at high elevation $(\mathrm{HR}=1)$ (Fig. 4).

Across the nine combinations of seed origin and plantation site, only seedlings with both seed origin and plantation site from low elevation showed significantly different death hazards (HR $=0.04$ [0.007-0.19], $p<0.001)$ compared to the reference seedlings (high elevation for both seed origin and plantation site, $H R=1$ ) (data not shown). Conversely, the differences in HR among the other combinations of seed origin and plantation site were not significant compared to the reference HRs.

\section{Discussion}

Overall, our results showed a low survival of planted seedlings during the experiment. We should be cautious when reporting and discussing the main model effect when interactions are highly significant. However, we detected that higher seedling survival and reduced death hazard were observed when seed origin differed from the plantation site. This was unexpected as previous studies found that the success of early recruitment of Spanish black pine was improved when seed and site origin matched (LucasBorja et al. 2016). For example, in a cross-sown experiment, Lucas-Borja et al. (2017) found that emergence for Spanish black pine seedlings depended on both soil and seed provenance and reported higher survival when these concurred. Nevertheless, available studies for pine species have reported contrasting results with some provenance trials reinforcing the existence of local adaptation (Savolainen et al. 2007, Alberto et al. 2013; Savolainen et al. 2013), whereas other field experiments did not find a significant interaction between seed origin and destination (Tíscar et al. 2018; Vizcaíno-Palomar et al. 2014). Where lower elevation families outperformed local families, it is possible that climate warming may have already disrupted local adaptation (Anderson and Wadgymar 2020).

Spanish black pine is considered a long-lived pine species with ecological and physiological adaptation traits to broad environmental conditions (Navarro-Cerrillo et al. 2018). Commonly studied traits for the mast-seeding Spanish black pine are the high genetic variation within populations
Fig. 4 Results of the Cox proportional regression model showing the hazard ratios for Spanish black pine's seedlings considering different factors in Cuenca Mountains (Spain). A hazard ratio $>1$ indicates increased in hazard, i.e., a lower seedling survival probability compared to the reference treatment contrast. The interaction between seed origin and plantation site is not shown

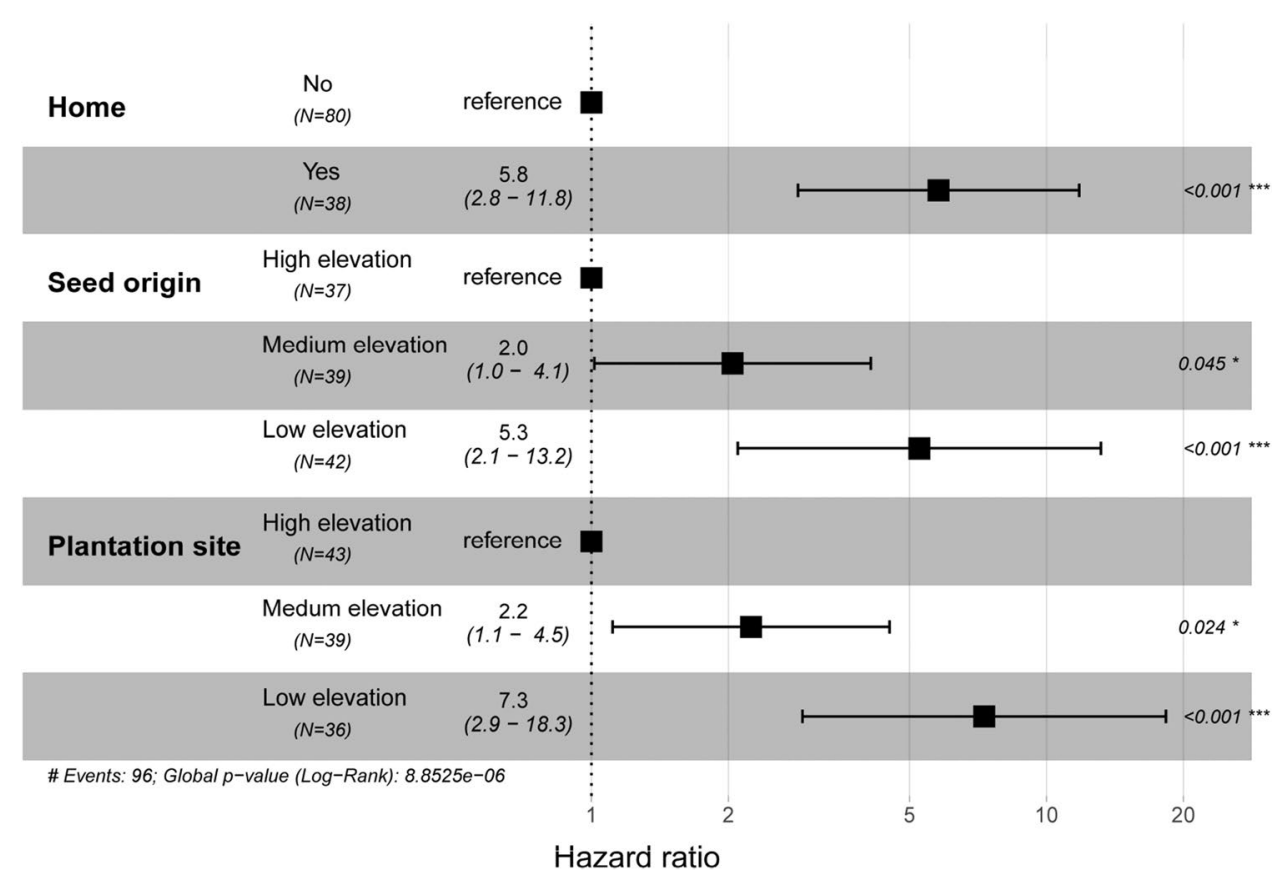


(Rubio-Moraga et al. 2012) and local adaptation at the seedling life stage (Alberto et al. 2013). However, previous findings have evidenced the lack of climatic adaptation of this species at early growth stages (Tiscar et al. 2018). Here we found that, according to the Kaplan-Meier test, seedling survival of Spanish black pine across seed origins was not significantly different. However, our results showed that survival was improved at medium and high elevations and that death hazard was higher at low and medium elevations, confirming our second hypothesis. Our results suggest that higher elevations with lower air temperature and more abundant precipitation rates can present more favourable climatic conditions for the establishment of Spanish black pine's seedlings. Together with the complete mortality recorded at the low elevation site, our findings underline the challenging natural regeneration of Spanish black pine under increasing dry conditions in the Mediterranean region (Linares and Tíscar 2010).

Spanish black pine, with a limited root system, is prone to desiccation (Vizcaíno-Palomar et al. 2014), particularly after dry and hot summers. In other Mediterranean areas like Southwest Turkey, increased spring/summer drought has been identified as the primary factor decreasing the vitality of black pine. In contrast, other areas, such as Western France, have seen an increase in this species' growth. These findings support the idea of decreased tree productivity at the equatorial range edges and poleward distribution shifts with increased global warming (Hickler et al. 2012) Although temperate forests may potentially benefit from warmer temperatures in the short-medium term, most experiments foresee a reduced productivity of Mediterranean forests due to increased droughts as well as fire incidence (Charru et al. 2017). In agreement with these studies, our field site observations during this experiment indicate that the total mortality of seedlings in low elevation sites was likely caused by the high temperatures and desiccation status reached during the summer. Enhancing the adaptive capacity of pines and other Mediterranean forests to climate change remains a challenge, in spite of the large efforts through several forest management strategies (Vilà-Cabrera et al. 2018). Strategies to increase drought stress resistance have commonly consisted of forest thinning (Calev et al. 2016), promoting mixed forests (del Río et al. 2017), or modifying species or genetic composition (Martín-Alcón et al. 2010). Here, we showed that the first bottleneck in Spanish black pine survival is the lack of resistance to drought in their initial life stages. Therefore, most efforts in forest management for this species should arguably go in that direction to pass through this filter.

Most reforestation and afforestation approaches have traditionally relied on locally sourced seeds, environmental conditions such as climate, soils, or geology at their home sites (Giencke et al. 2018). These approaches may, however, oversee some implications on the survival of remnant populations via over collection of seeds or through changes in the species composition of the remnant sites (Meissen et al. 2015). Furthermore, climate change could further reduce seed availability and supply and affect home-site advantages as genetic adaptations become decoupled from the historic climatic conditions ranges under which they developed (Prober et al. 2015).

On this study, it is worthy to note that seedlings were cultivated with different soil media which might result in different seedling quality for seed origin. Although nursery cultivation was short in time, seed origin effects can be confounded by soil properties because seedlings were cultivated using soil from their own sites. Altogether, our results highlight that, although natural selection may filter the survival of well-established seedlings or seedlings, seedling survival in the first year is strongly depends on environmental conditions (Vizcaíno-Palomar et al. 2014; Tiscar et al. 2018). Afforestation efforts to enhance adaptation of these forests in future climate scenarios will then require a combination of methods such as the selection of more drought-resistant genotypes and species, but more importantly the transformation to mixed, multi-aged forest stands (Vizcaíno-Palomar et al. 2014). These measures could promote the forest structural diversity (i.e., uneven-aged forests) to enhance resistance and recovery capacity through niche partitioning and differential response to stressors (de-Dios-García 2015). Using transplanted seedlings previously nurtured in a treenursery instead of seeds can partially overcome the seedling emergence bottleneck under extreme environmental conditions (Lucas-Borja et al. 2017), but as demonstrated here, the extreme climate will have a serious effect on the survival of this species even passed this life stage.

\section{Conclusion}

This study assessed the effects of seed origin and plantation site on the early recruitment of Spanish black pine along a natural gradient with contrasting elevation and climatic conditions. We found that plantation site is more important than seed origin for the success of early recruitment of Spanish black pine. Plantation site was significantly associated with the duration of seedling survival, whereas mean seedling survival rate and probability were similar for all the studied seed origins. Nonetheless, some groups of seeds translocated from warmer to colder plantation sites (from low to high elevation or from medium to high elevation) showed significantly higher seedling survival rates. These results suggest that seedlings of Spanish black pine translocated from warmer and drier seed origins for afforestation aims could potentially increase early species recruitment in naturally 
regenerated forests. Our results evidenced that the first bottleneck in Spanish black pine survival through afforestation is the lack of resistance to drought in their initial life stages. These results have direct implications in forest management of the Cuenca Mountains and the overall Mediterranean region where Spanish black pine distributes, particularly in current and future climate change scenarios.

Acknowledgements The authors thank Dr. Pedro Antonio Tíscar Oliver (Junta de Andalucía, Spain) for research and field assistance. MMR is supported by the Australian Research Council Discovery Early Career Research Award DE180100570.

Author contribution statement MELB and DCP conceived of the presented idea and carried out the experiment. MELB, XJ, MP; FR; MH and MMR contributed to the interpretation of the results. MELB, MMR. FR, and DAZ wrote the manuscript with input from all authors. All authors revised and approved de manuscript.

\section{Declarations}

Conflict of interest The authors declare no conflict of interest.

Open Access This article is licensed under a Creative Commons Attribution 4.0 International License, which permits use, sharing, adaptation, distribution and reproduction in any medium or format, as long as you give appropriate credit to the original author(s) and the source, provide a link to the Creative Commons licence, and indicate if changes were made. The images or other third party material in this article are included in the article's Creative Commons licence, unless indicated otherwise in a credit line to the material. If material is not included in the article's Creative Commons licence and your intended use is not permitted by statutory regulation or exceeds the permitted use, you will need to obtain permission directly from the copyright holder. To view a copy of this licence, visit http://creativecommons.org/licenses/by/4.0/.

\section{References}

Alberto FJ, Aitken SN, Alía R, González-Martínez SC, Hänninen $\mathrm{H}$, Kremer A, Lefèvre F, Lenormand T, Yeaman S, Whetten R, Savolainen O (2013) Potential for evolutionary responses to climate change-evidence from tree populations. Glob Chang Biol 19:1645-1661. https://doi.org/10.1111/gcb.12181

Anderson JT, Wadgymar SM (2020) Climate change disrupts local adaptation and favours upslope migration. Ecol Lett 23:181-192. https://doi.org/10.1111/ele.13427

Barbéro M, Oisel R, Quézel P, Richardson D, Romane F (1998) Pines of the Mediterranean Basin. In: Richardson DM (ed) Ecology and biogeography of Pinus. Cambridge University Press, Cambridge

Bischoff A, Steinger T, Müller-Schärer H (2010) The importance of plant provenance and genotypic diversity of seed material used for ecological restoration. Restor Ecol 18:338-348. https://doi. org/10.1111/j.1526-100X.2008.00454.x

Calev A, Zoref C, Tzukerman M, Moshe Y, Zangy E, Osem Y (2016) High-intensity thinning treatments in mature Pinus halepensis plantations experiencing prolonged drought. Eur J for Res 135:551-563. https://doi.org/10.1007/s10342-016-0954-y

Campo J, Stijsiger RJ, Nadal-Romero E, Cammeraat ELH (2019) The effects of land abandonment and long-term afforestation practices on the organic carbon stock and lignin content of Mediterranean humid mountain soils. Eur J Soil Sci 70:947-959. https://doi.org/ 10.1111/ejss. 12799

Charru M, Seynave I, Hervé J-C, Bertrand R, Bontemps J-D (2017) Recent growth changes in Western European forests are driven by climate warming and structured across tree species climatic habitats. Ann for Sci 74:33. https://doi.org/10.1007/ s13595-017-0626-1

de Dios-García J, Pardos M, Calama R (2015) Interannual variability in competitive effects in mixed and monospecific forests of Mediterranean stone pine. For Ecol Manage 358:230-239. https://doi.org/10.1016/j.foreco.2015.09.014

del Cerro Barja A, Lucas Borja ME, Martínez García E, López Serrano FR, Andrés Abellán M, García Morote FA, Navarro López $R$ (2009) Influence of stand density and soil treatment on the Spanish Black Pine (Pinus nigra Arn. ssp. Salzmannii) regeneration in Spain. For Syst 18:1-14. https://doi.org/10.5424/fs/ 2009182-01060

del Río M, Pretzsch H, Ruíz-Peinado R, Ampoorter E, Annighöfer P, Barbeito I, Bielak K, Brazaitis G, Coll L, Drössler L, Fabrika M, Forrester DI, Heym M, Hurt V, Kurylyak V, Löf M, Lombardi F, Madrickiene E, Matović B, Mohren F, Motta R, den Ouden J, Pach M, Ponette Q, Schütze G, Skrzyszewski J, Sramek V, Sterba H, Stojanović D, Svoboda M, Zlatanov TM, Bravo-Oviedo A (2017) Species interactions increase the temporal stability of community productivity in Pinus sylvestrisFagus sylvatica mixtures across Europe. J Ecol 105:1032-1043. https://doi.org/10.1111/1365-2745.12727

Djorović M, Isajev V, Kadović R (2003) Systems of afforestation and grass cover in erosion control

Dulamsuren C, Hauck M, Leuschner C (2013) Seedling emergence and establishment of Pinus sylvestris in the Mongolian foreststeppe ecotone. Plant Ecol 214:139-152. https://doi.org/10. 1007/s11258-012-0152-z

El-Keblawy A, Ksiksi T (2005) Artificial forests as conservation sites for the native flora of the UAE. For Ecol Manage 213:288296. https://doi.org/10.1016/j.foreco.2005.03.058

Fiandino SI, Plevich JO, Tarico JC, Nuñez C, Rusch V, Gyenge JE (2018) Effects of low-density Pinus elliottii (Slash pine) afforestation on environmental conditions and native plant diversity, in the mountains of central Argentina. Appl Veg Sci 21:442-450. https://doi.org/10.1111/avsc.12385

Giencke LM, Carol Denhof R, Katherine Kirkman L, Stribling Stuber O, Brantley ST (2018) Seed sourcing for longleaf pine ground cover restoration: using plant performance to assess seed transfer zones and home-site advantage. Restor Ecol 26:11271136. https://doi.org/10.1111/rec.12673

Gray LK, Hamann A, John S, Rweyongeza D, Barnhardt L, Thomas BR (2016) Climate change risk management in tree improvement programs: selection and movement of genotypes. Tree Genet Genomes. https://doi.org/10.1007/s11295-016-0983-1

Hernández J, del Pino A, Vance ED, Califra Á, Del Giorgio F, Martínez L, González-Barrios P (2016) Eucalyptus and Pinus stand density effects on soil carbon sequestration. For Ecol Manage 368:28-38. https://doi.org/10.1016/j.foreco.2016.03.007

Hickler T, Vohland K, Feehan J, Miller PA, Smith B, Costa L, Giesecke T, Fronzek S, Carter TR, Cramer W, Kühn I, Sykes MT (2012) Projecting the future distribution of European potential natural vegetation zones with a generalized, tree speciesbased dynamic vegetation model. Glob Ecol Biogeogr 21:5063. https://doi.org/10.1111/j.1466-8238.2010.00613.x

Löf M, Madsen P, Metslaid M, Witzell J, Jacobs DF (2019) Restoring forests: regeneration and ecosystem function for the future. New for 50:139-151. https://doi.org/10.1007/s11056-019-09713-0

Lucas-Borja ME, Van Stan JT, Heydari M, Omidipour R, Rocha F, Plaza-Alvarez PA, Zema DA, Muñoz-Rojas M (2020) Postfire restoration with contour-felled $\log$ debris increases early 
recruitment of Spanish black pine (Pinus nigra Arn ssp salzmannii) in Mediterranean forests. Restor Ecol. https://doi.org/ 10.1111/rec. 13338

Martín-Alcón S, González-Olabarría J, Coll L (2010) Wind and snow damage in the Pyrenees pine forests: effect of stand attributes and location. Silva Fenn. https://doi.org/10.14214/sf.138

Mathiasen P, Premoli AC (2016) Living on the edge: adaptive and plastic responses of the tree Nothofagus pumilio to a long-term transplant experiment predict rear-edge upward expansion. Oecologia 181:607-619. https://doi.org/10.1007/ s00442-016-3568-7

Meissen JC, Galatowitsch SM, Cornett MW (2015) Risks of overharvesting seed from native tallgrass prairies. Restor Ecol 23:882891. https://doi.org/10.1111/rec.12295

Moles AT, Westoby M (2004) What do seedlings die from and what are the implications for evolution of seed size? Oikos 106:193-199. https://doi.org/10.1111/j.0030-1299.2004.13101.x

Morales-Molino C, Colombaroli D, Valbuena-Carabaña M, Tinner W, Salomón RL, Carrión JS, Gil L (2017) Land-use history as a major driver for long-term forest dynamics in the Sierra de Guadarrama National Park (central Spain) during the last millennia: implications for forest conservation and management. Glob Planet Change 152:64-75. https://doi.org/10.1016/j.gloplacha.2017.02. 012

Niu X, Duiker SW (2006) Carbon sequestration potential by afforestation of marginal agricultural land in the Midwestern U.S. For Ecol Manage 223:415-427. https://doi.org/10.1016/j.foreco.2005. 12.044

Ockendon N, Thomas DHL, Cortina J, Adams WM, Aykroyd T, Barov B, Boitani L, Bonn A, Branquinho C, Brombacher M, Burrell C, Carver S, Crick HQP, Duguy B, Everett S, Fokkens B, Fuller RJ, Gibbons DW, Gokhelashvili R, Griffin C, Halley DJ, Hotham P, Hughes FMR, Karamanlidis AA, McOwen CJ, Miles L, Mitchell R, Rands MRW, Roberts J, Sandom CJ, Spencer JW, ten Broeke E, Tew ER, Thomas CD, Timoshyna A, Unsworth RKF, Warrington S, Sutherland WJ (2018) One hundred priority questions for landscape restoration in Europe. Biol Conserv 221:198-208. https://doi.org/10.1016/j.biocon.2018.03.002

Ordóñez JL, Retana J (2004) Early reduction of post-fire recruitment of Pinus nigra by post-dispersal seed predation in different timesince-fire habitats. Ecography (cop) 27:449-458. https://doi.org/ 10.1111/j.0906-7590.2004.03886.x

Parhizkar M, Shabanpour M, Khaledian M, Cerdà A, Rose CW, Asadi H, Lucas-Borja ME, Zema DA (2020) Assessing and modeling soil detachment capacity by overland flow in forest and woodland of northern Iran. Forests 11:65. https://doi.org/10.3390/f11010065

Prober S, Byrne M, McLean E, Steane D, Potts B, Vaillancourt R, Stock W (2015) Climate-adjusted provenancing: a strategy for climate-resilient ecological restoration. Front Ecol Evol. https:// doi.org/10.3389/fevo.2015.00065

Rubio-Moraga A, Candel-Perez D, Lucas-Borja ME, Tiscar PA, Viñegla B, Linares JC, Gómez-Gómez L, Ahrazem O (2012) Genetic diversity of Pinus nigra Arn. populations in Southern Spain and Northern Morocco revealed by inter-simple sequence repeat profiles. Int J Mol Sci 13:5645-5658. https://doi.org/10. 3390/ijms 13055645
Savolainen O, Lascoux M, Merilä J (2013) Ecological genomics of local adaptation. Nat Rev Genet 14:807-820. https://doi.org/10. $1038 /$ nrg3522

Tíscar P, Linares J (2014) Large-scale regeneration patterns of Pinus nigra subsp. salzmannii: poor evidence of increasing facilitation across a drought gradient. Forests 5:1-20. https://doi.org/10.3390/ f5010001

Tíscar PA, Lucas-Borja ME, Candel-Pérez D (2018) Lack of local adaptation to the establishment conditions limits assisted migration to adapt drought-prone Pinus nigra populations to climate change. For Ecol Manage 409:719-728. https://doi.org/10.1016/j. foreco.2017.12.014

Vázquez-Ramírez J, Venn SE (2021) Seeds and seedlings in a changing world: a systematic review and meta-analysis from high altitude and high latitude ecosystems. Plants. https://doi.org/10.3390/plant s10040768

Vilà-Cabrera A, Coll L, Martínez-Vilalta J, Retana J (2018) Forest management for adaptation to climate change in the Mediterranean basin: a synthesis of evidence. For Ecol Manage 407:16-22. https://doi.org/10.1016/j.foreco.2017.10.021

Vizcaíno-Palomar N, Revuelta-Eugercios B, Zavala MA, Alía R, González-Martínez SC (2014) The role of population origin and microenvironment in seedling emergence and early survival in Mediterranean maritime pine (Pinus pinaster Aiton). PLoS ONE 9:e109132. https://doi.org/10.1371/journal.pone.0109132

Walder T, Erschbamer B (2015) Temperature and drought drive differences in germination responses between congeneric species along altitudinal gradients. Plant Ecol 216:1297-1309. https://doi.org/ 10.1007/s11258-015-0509-1

Wang Y, Pedersen JLM, Macdonald SE, Nielsen SE, Zhang J (2019) Experimental test of assisted migration for conservation of locally range-restricted plants in Alberta, Canada. Glob Ecol Conserv. https://doi.org/10.1016/j.gecco.2019.e00572

Wenhua L (2004) Degradation and restoration of forest ecosystems in China. For Ecol Manage 201:33-41. https://doi.org/10.1016/j. foreco.2004.06.010

Willemen L, Barger NN, ten Brink B, Cantele M, Erasmus BFN, Fisher JL, Gardner T, Holland TG, Kohler F, Kotiaho JS, von Maltitz GP, Nangendo G, Pandit R, Parrotta JA, Potts MD, Prince SD, Sankaran M, Brainich A, Montanarella L, Scholes R (2020) How to halt the global decline of lands. Nat Sustain 3:164-166. https:// doi.org/10.1038/s41893-020-0477-x

Zaghi D (2008) Management of Natura 2000 habitats: (Sub-) Mediterranean pine forests with endemic black pines

Zeng L, He W, Teng M, Luo X, Yan Z, Huang Z, Zhou Z, Wang P, Xiao W (2018) Effects of mixed leaf litter from predominant afforestation tree species on decomposition rates in the Three Gorges Reservoir, China. Sci Total Environ 639:679-686. https://doi.org/ 10.1016/j.scitotenv.2018.05.208

Publisher's Note Springer Nature remains neutral with regard to jurisdictional claims in published maps and institutional affiliations. 